\title{
A case of subacute effusive constrictive pericarditis with a probable amoebic aetiology
}

\author{
C S BAID, ANOOP R VARMA, MANOJ LAKHOTIA \\ From the Department of Medicine, SMS Medical College Hospital, Jaipur, India
}

SUMMARY A 48 year old man with amoebic pericarditis did not improve after pericardiocentesis. Facilities for echocardiography and haemodynamic studies were not available. Cardiac compression was suspected and at emergency pericardiectomy subacute effusive constrictive amoebic pericarditis was found. The patient recovered.

This is believed to be the first report of a case of subacute effusive constrictive pericarditis caused by amoebiasis.

A 48 year old man was admitted on 14 April 1986 with a one month history of shortness of breath, left chest pain, fever, oedema of the feet, and progressive weakness. On examination he was toxic, febrile, and anaemic and had pedal oedema. His pulse was 110 beats/minute, feeble, and regular; blood pressure was $80 / 60 \mathrm{~mm} \mathrm{Hg}$ and a pulsus paradoxus was present. The central venous pressure was $25 \mathrm{~cm}$ of saline. The apex beat was not palpable and the first and second heart sounds were feeble. A pleuropericardial rub was also detected. The liver was palpable $8 \mathrm{~cm}$ below the right costal margin and was tender.

Routine investigations showed haemoglobin $92 \mathrm{~g} / \mathrm{l}$, total leucocytes $18000 / \mathrm{mm}^{3}$, erthrocyte sedimentation rate $30 \mathrm{~mm} / 1 \mathrm{st} \mathrm{h}$, no abnormality of urine or stool, blood urea $17.85 \mathrm{mmol} / \mathrm{l}$, serum creatinine $176.8 \mu \mathrm{mol} / \mathrm{l}$, serum total proteins $60 \mathrm{~g} / \mathrm{l}$, serum albumin $27 \mathrm{~g} / \mathrm{l}$, serum globulin $33 \mathrm{~g} / \mathrm{l}$, serum alkaline phosphatase $0.35 \mu \mathrm{kat} / 1$. Serum electrolytes, concentrations of serum transaminases and serum bilirubin were normal. The chest $x$ ray (posterior/anterior view) was suggestive of pericardial effusion, with a cardiothoracic ratio of $0 \cdot 7$. Electrocardiography did not reveal any abnormality. Facilities for echocardiography and haemodynamic studies were not available.

A provisional diagnosis of cardiac tamponade was made and within two hours of admission an emergency pericardiocentesis was performed via the epigastric approach. It yielded $300 \mathrm{ml}$ of anchovy

Requests for reprints to Dr C S Baid, K-15 Malviya Marg, C-Scheme, Jaipur 302001, India. sauce pus. But this did not produce any appreciable change in the patient's pulse, blood pressure, or central venous pressure. There was a slight improvement in symptoms though. The patient was then treated with intravenous fluids, metronidazole, and dehydroemetine.

The next day a liver scan with technetium-99m (phytate) revealed considerable hepatomegaly and a reduced uptake over the upper left lobe and upper medial right lobe. Aspiration of the liver abscess on two occasions, at an interval of two days, yielded $800 \mathrm{ml}$ of anchovy sauce pus. No amoebae were found in the pericardial pus. Medication was continued. There was not much relief of his symptoms and blood pressure remained at $80 / 60 \mathrm{~mm} \mathrm{Hg}$, pulse 120 beats/minute, temperature $38^{\circ} \mathrm{C}$, and central venous pressure $24 \mathrm{~cm}$ of saline. We then suspected cardiac compression and decided to operate although he was clearly a poor risk patient. At operation $150 \mathrm{ml}$ of anchovy sauce pus under tension was released and we removed the thick parietal and visceral pericardium overlying the ventricles.

Immediately after operation pulse rate settled at $\tilde{\sigma}$ $90 / \mathrm{min}$, the blood pressure rose to $110 / 70 \mathrm{~mm} \mathrm{Hg}$, N and the central venous pressure fell to $8 \mathrm{~cm}$ of saline. N A postoperative chest $x$ ray showed a normal cardio- $O$ thoracic ratio. He was treated with digoxin, met- 0 ronidazole, and blood transfusions. We kept a close $\frac{}{\Phi}$ watch on him for ten days and he was discharged on $\stackrel{?}{?}$ 5 May 1986 in good health.

\section{Pathological examination}

Histopathological examination of the excised peri- $\stackrel{\AA}{\circ}$ cardium showed a complete loss of mesothelial cells 
and the surface was covered with a granular exudate containing nuclear debris and a large number of ghost cells with karyolytic nuclei. Beneath this exudate was a layer of fibrin and collagenous tissue. The rest of the tissue showed subepicardial fat containing proliferating fibroblasts and lymphocytic infiltrate. The inflammatory response was not pronounced. No neutrophils could be demonstrated. Although we did not find Entamoeba histolytica, we did see occasional structures in the superficial necrotic exudate that appeared to be degenerated entamoebae.

\section{Discussion}

At admission this appeared to be a case of cardiac tamponade. Emergency pericardiocentesis produced only partial and temporary relief. Subsequent pericardiectomy yielded $150 \mathrm{ml}$ of anchovy sauce pus under tension. The visceral pericardium was thick and constrictive. After pericardiectomy the patient improved remarkably and remains symptom free. The clinical picture and findings at operation suggest that this was a case of amoebic subacute effusive constrictive pericarditis.

Subacute effusive constrictive pericarditis ${ }^{12}$ is diagnosed when the right atrial pressure remains raised after the intrapericardial pressure has been reduced to normal by the removal of pericardial fluid. Pericardiocentesis produces only partial or no relief in signs and symptoms. At operation there is extensive thickening of the parietal and visceral pericardium and the free pericardial space contains $100-150 \mathrm{ml}$ of fluid under tension. ${ }^{1}$

The most common causes ${ }^{3}$ of subacute effusive constrictive pericarditis are idiopathic ${ }^{1}$ or presumed viral pericarditis, ${ }^{3}$ tuberculosis, ${ }^{4}$ neoplastic infiltration of the pericardium, ${ }^{56}$ and mediastinal irradiation. ${ }^{17}$ Other causes are viral, ${ }^{8}$ acute pyogenic pericarditis, ${ }^{9-11}$ a uraemic $^{12}$ and post traumatic pericarditis. ${ }^{13}$ Amoebic pericarditis is a rare ${ }^{14}$ complication of amoebic liver abscess. We know of no other reports of amoebic pericarditis causing subacute effusive constriction. In a case of pericarditis reported by Kala and Sharma a total of $1500 \mathrm{ml}$ fluid was drained from the pericardial cavity on two separate occasions. ${ }^{15}$ Finally their patient had to be treated by pericardiectomy and there was evidence of cardiac constriction. We feel that they too were treating a case of amoebic subacute effusive constrictive pericarditis.

In our case the coexistence of an abscess in the left lobe of the liver together with pericardial effusion suggested an amoebic cause. Although Entamoeba histolytica was not found in the pericardial fluid, the absence of acute inflammation in the pericardium and the aspiration of anchovy sauce pus from both the liver abscess and the pericardial sac were considered to be diagnostic of amoebic pericarditis. Entamoeba histolytica is rarely demonstrable in the pericardial fluid but the diagnosis can be based on aspiration of anchovy sauce pus from the pericardial cavity. ${ }^{16}$

When amoebic subacute effusive constrictive pericarditis is suspected haemodynamic studies should be performed and if they indicate subacute effusive constriction, pericardiectomy should be performed immediately. ${ }^{1}$ If operation is delayed constrictive pericarditis will develop with myocardial infiltration. ${ }^{13}$ If there are no facilities for haemodynamic studies management will be determined by the clinical symptoms, pulse, blood pressure, and the central venous pressure. If after pericardiocentesis blood pressure remains low, the central venous pressure does not fall, and tachycardia persists, an underlying cardiac constriction should be suspected. Constriction, if present, will be confirmed at operation, as happened in our case.

\section{References}

1 Hancock EW. Subacute effusive-constrictive pericarditis. Circulation 1971;43:183-92.

2 Rasaretnam R, Chanmugam D. Subacute effusive constrictive epicarditis. Br Heart J 1980;44:44-8.

3 Beverly HL, Braunwald E. Pericardial disease. In: Braunwald E, ed. Heart disease. A text book of cardiovascular medicine. 2nd ed. Philadelphia: WB Saunders, 1984:1496.

4 Wood P. Chronic constrictive pericarditis. Am J Cardiol 1961;7:48-61.

5 Spodick DH, Kumar S. Subacute constrictive pericarditis with cardiac tamponade. Dis Chest 1968;54:62-6.

6 Mann T, Brodie BR, Grossman W, McLaurin L. Effusive-constrictive hemodynamic pattern due to neoplastic involvement of the pericardium. $\mathrm{Am} \mathrm{J}$ Cardiol 1978;41:781-6.

7 Steinberg I. Effusive constrictive radiation pericarditis. Two cases illustrating value of angiocardiography in diagnosis. Am J Cardiol 1967;19:434-9.

8 Cooper DKC, Sturridge MF. Constrictive epicarditis following Coxsackie virus infection. Thorax 1976;31: 472-4.

9 Rubinstein JJ, Goldblatt A, Daggett WM. Acute constriction complicating purulent pericarditis in infancy. Am J Dis Child 1972;124:591-4.

10 Scott LP, Knox D, Perry LW, Pineros-Torres FJ. Meningococcal pericarditis; report of two cases, one complicated by acute constrictive pericarditis. $\mathrm{Am} \mathrm{J}$ Cardiol 1972;29:104-8.

11 Ehrich DA, Widmann JJ, Abelmann WH. Acute effusive constrictive Straphylococcal pericarditis. 
Chest 1975;67:721-3.

12 Spaulding WB. Subacute constrictive uremic pericarditis. Arch Intern Med 1967;119:644-7.

13 Mullen DC, Dillon ML, Young WG Jr, Sealy WC, Durham NC. Pericardiectomy in non-tuberculous pericarditis. J Thorac Cardiovasc Surg 1969;58: 517-29.
14 Juniper K. Amoebiasis. Clinics in gastroenterology. London: WB Saunders, 1978:7:3-29.

15 Kala PC, Sharma GC. Amoebic pericarditis treated by pericardiectomy. J Indian Med Assoc 1980;74:194-6.

16 Kulpati DD, Venkatachalam CG, Saha NC. Amoebic pericarditis-a case report. J Assoc Physicians India 1976;24:119-22.

\section{Notices}

\section{British Cardiac Society}

The Autumn Meeting will be held at the Wembley Conference Centre, London, on 24 to 26 November 1987, and the closing date for receipt of abstracts was 10 July 1987.

The Annual General Meeting for 1988 will take place in Belfast on 23 and 24 March 1988, and the closing date for receipt of abstracts will be 4 January 1988.

\section{International Society of Heart Research}

The Tenth European Meeting of the International Society of Heart Research will be held in Rotterdam on 7 to 9 September 1989. Inquiries to: Office for Post Graduate Medical Education, Erasmus University Rotterdam, PO Box 1738, 3000 DR Rot- 은 terdam, The Netherlands.

\section{World Congress of Cardiology}

The XI World Congress of Cardiology will be held at the Philippine International Convention Center, Manila, on 11 to 16 February 1990. Inquiries to: Organising Committee, XI World Congress of Cardiology, Philippine Heart Center, East Avenue, Quezon City, The Philippines. 